\title{
Five new South African short operas: a report
}

\author{
Bertha Spies \\ Department of Music, University of Pretoria, Pretoria, 0002 \\ e-mail: spies.bertha@gmail.com
}

The University of Cape Town commissioned five South African composers to write a 20-minute opera each in celebration of the centenary of the South African College of Music. The Gordon Institute for Performing and Creative Arts (GIPCA) funded the composition and production of the operas, presented collectively as Five:20 Operas Made in South Africa. ${ }^{1}$ The operas were presented by Cape Town Opera, the University of Cape Town Opera School and GIPCA from 21 to 27 November 2010 in the Baxter Theatre in Rondebosch under the auspices of the University of Cape Town. ${ }^{2}$

Although Michael Williams, Managing Director of Cape Town Opera, regards the time constraint as 'a thrilling challenge to strip opera down to the essentials: story, music and voice' (Henry 2010), it must have been a daunting experience for composers and librettists to fit a convincing storyline into a 20 -minute production and they must have had to make difficult choices with regard to content. The five composers, Bongani Ndodana-Breen, Hendrik Hofmeyr, Martin Watt, Peter Klatzow and Péter Louis van Dijk (in order of performance), were asked to compose a short opera on a South African topic. The orchestration was prescribed (most probably for practical and financial reasons) and, although GIPCA made suggestions about libretti, the composers eventually chose their own texts. The operas were directed by Marcus Desando (Hani and Tronkvoël) and Geoffrey Hyland (Saartjie, Words from a Broken String and Out of Time). The first and last operas of the evening dealt with the South Africa of today, whereas the themes of the middle three operas refer to our past.

The five South African operas, the main focus of this review, ${ }^{3}$ were preceded by a special guest performance of Sublimation, a 15-minute opera by Nick Fells (libretto by Zoë Strachan). Sublimation formed part of Scottish Opera's Five:15 Operas Made in Scotland, from which the idea for the South African Five:20 project was derived. In

\footnotetext{
1 The programme also acknowledges the following institutions as supporters of the project: the National Lottery Distribution Trust Fund, the Andrew W Mellon Foundation, the Scottish Government, Scottish Opera, the South African College of Music and the office of the Dean of Humanities of the University of Cape Town.

2 GIPCA was established in December 2008 by Sir Donald Gordon, the founder of Liberty Life. See $<\mathrm{http}: / /$ www.uct.ac.za/about/arts/gipca/ $>$ for further information on GIPCA.

3 For reviews of the productions see Irish (2010), Brommert (2010) and Muller (2010).
} 
Sublimation, with its evocative music, two sisters and the little boy of one of them gather flowers on the shore of a lake. The mother is haunted by traumatic memories from her past, but the nature of the eventual sublimation is left to the audience to interpret.

Bongani Ndodana-Breen's Hani, the first South African opera on the programme, takes the assassination of Chris Hani on 10 April 1993 as its point of departure to ask questions about post-apartheid South Africa. The first scene shows the character of The Librettist, Mfundi Vundla, in his study in the middle of the night, remembering his personal meeting with Hani during his exile in Los Angeles. For many people, Tshonyane (as Hani is most often referred to in the opera) represents the voice of ordinary people - 'he was not self-centred, big headed and elitist. He was not preoccupied with material things' (Vavi 2010). According to The Librettist's monologue, the text that he is writing 'calls upon the spirit of Chris Hani to help us navigate in this new South Africa' (Rutter 2010). Ndodana-Breen feels it is important to 'speak to the events of our time and in a language (text and music) that reaches out to the majority of our fellow citizens'. To reach this objective, he uses the indigenous music language that he is most familiar with: 'I am Xhosa, I was born that way and that is something that I cannot help in my music. It comes out [...] the music and harmonies of our people, our modes and rhythms, our harmonic language, how we use music and dance in our daily lives' (2010).

In the opera Hani static bands of sound (bars 12-32 in crotchets, 66-84 and 103-119 in quavers, etc.) are initially based on the synchronic or asynchronic combination of a repeated three-note pattern, which is first heard as an isolated angular motive in bar 4 (crotchets D, G, A played by the viola). The range of the band of sound, played by the flute, clarinet and marimbas, becomes wider and the inner angularity is heightened when, marked 'as if in a dream', it issues in the characteristic call of the Soothsayer ('Come back! We say come back Tshonyane'). ${ }^{4}$

Example 1: Hani, bars $85-89^{1}$ (Soothsayer)

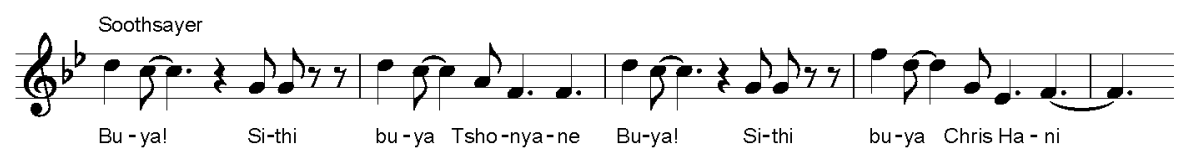

\footnotetext{
It is not possible to do justice to five operas within the limited scope of a review. Therefore, I have chosen to comment on those musical events which struck me on first hearing when I attended the performance. The accompaniment is omitted in the music examples, with the exception of Example 3.2, which has no accompaniment.
} 
Re-enacting an ancient ritual in which the corpses of ancestors are removed from their tombs to become guests of honour at a party expresses the belief that keeping the ancestors happy means that they "will intervene positively in the earthly life of the family'. ${ }^{5}$ After the exhumation ceremony has begun, and the people ask 'Chris Hani! Permit us to exhume you!', the isolated G, F ('Zitsho') in the middle of the phrase completes the pentatonic scale which is suggested by the four-part singing of the people

Example 2: Hani, bars 260-263 (Imbongi, Soothsayer, choir)

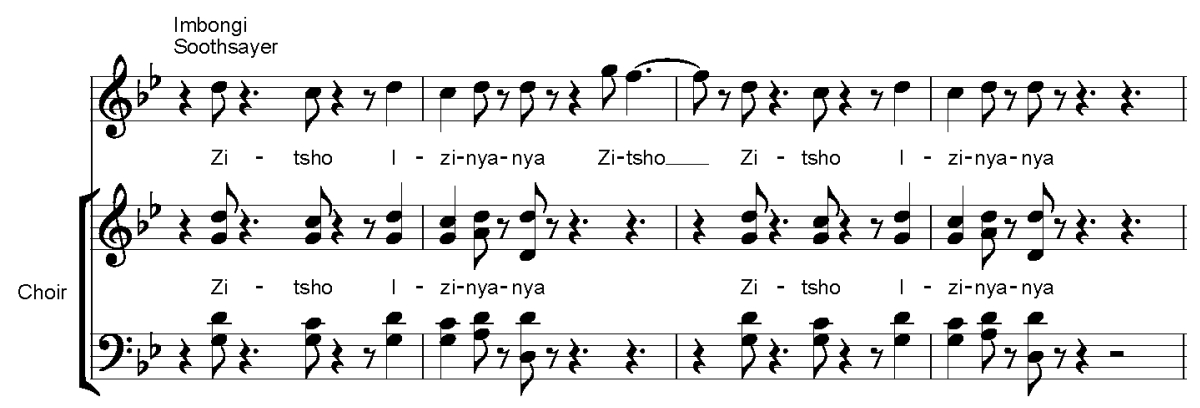

The opera finally climaxes when in the final 21 bars of the opera the choir and soloists singing 'Zitsho izinyanya' ('We told you Ancestor') is accompanied by a static band of sound, only interrupted by the choir singing an abbreviated version of the Soothsayer's call (Example 1.1) in bars 268-270.

A pentatonic effect has been suggested from the beginning of the opera when the altos open with an isolated ascending whole tone in bar 6 ('Wena', 'You') and 'Buya! Sithi buya Tshonyane', 'Come back! We say come back Tshonyane', (Example 1.1) is set in a pentatonic environment. The exception is $\mathrm{E}^{b}$ (against 'Ha-' of 'Chris Hani' in bar 88), which also creates an ascending whole tone at the closing of the phrase, linking with the questioning effect of the isolated 'Wena' at the beginning of the opera. Appearing just before the general pause, 17 bars before the end, the words 'Chris Hani' are left out and the phrase becomes fully pentatonic, referring only to Tshonyane and ending with a falling minor third against 'Buya!' ('Come back!'), as if lamenting his absence.

The 'hole in the nation's bucket' (choir bar 98, also bars 189 and 249) signifies the need for a strong political leader such as Chris Hani. Vundla explains that the libretto asks Hani to plug the hole in the nation's bucket because '[t]here are some citizens who are very concerned about the moral compass of this country - how we treat

5 Unless stated otherwise, all quotations are from the programme notes (2010). 
foreigners and women, the corruption in our society' (Rutter 2010). According to the programme notes, the libretto also 'compares the masses in our young democracy to the Panther in Rilke's poem', the Panther being trapped in a cage - 'powerful yet paralysed'.

Hendrik Hofmeyr, who, apart from the music, also wrote the libretto for Saartjie in collaboration with Fiona Zerbst, chose Saartjie Baartman as the subject for his opera, because he was attracted to the concept of the archetypical tragic heroine (Hofmeyr 2010). He wanted 'to untangle the myth of Saartjie Baartman from the real woman who was more than an African victim of European exploitation'. Hofmeyr argues that Saartjie knew precisely what she was doing and that the contract to go overseas was lucrative: ' $[\mathrm{N}] \mathrm{o}$ other showgirl, then or now, would normally get 50 percent of the profits of the show. [...] If you look at the famous posters of her showing her sideways and full front, at the bottom in small print it says 'Copyright Saartjie Baartman', which makes her South Africa's first female publisher' (Chisholm 2010). ${ }^{6}$

The opera focuses on the night that Saartjie died in Paris, New Year's Eve 1815. Famous as the 'Hottentot Venus', she returns exhausted from one of her exhibitions and vows not to let her manager, Reaux, force her to continue exhibiting herself. Remembering an Afrikaans song reminds her of her Cape lover, Daniel, with whom she had a child, Elsie. After becoming confused on hearing 'La Marseillaise', she is upset when hearing the crowd outside singing a ribald song about her. In a daze she hums the Nguni lullaby which she used to sing to Elsie. Hearing the cannons at midnight, she tries to find solace in a Khoi prayer remembered from her childhood, while for her the cannons become the thunder and the distant fireworks the stars of Africa. She dies hearing her ancestors calling her to come home.

As Saartjie is the only character in the opera, the drama is of a psychological nature. Three existing songs, which represent three different times and places in her life, plot out the course of this drama. These songs refer to her past, present and future, beginning with the nostalgic Afrikaans song, 'Al lê die berge nog so blou'. This song is not only a tribute to the wonderful times she had spent with Daniel, her Bavarian 'drummerboy' in Cape Town, it can also refer to the blue Kouga mountains where she was born. The relentlessness of time marching on is signified by 'La Marseillaise' sung by a crowd of passers-by, staring straight ahead, dressed in period costume. The Nguni

6 See also Sara Baartman and the Hottentot Venus by Crais and Scully (2009). 
lullaby, 'Thula', not only symbolises an imminent return to her indigenous African roots, but also to a spiritual home of eternal peace.

Following this line of development helps to make sense of the apparently surreal music with which the opera opens. Hearing the unsettling abrupt musical gestures, the jagged melodic motives, the complex vertical structures, and later on the highly active and dense accompaniment textures and the unsettling trills, one wonders what this has to do with a seemingly simple woman from the Eastern Cape. However, this complexity makes sense when eventually the lullaby is heard at the end - the elegance of its melodic contours and the openness of the quartal structures of the accompaniment symbolising a point of arrival, a point of rest.

Although the opening orchestral material reappears unvaried later in the opera (starting at bars 51 and 408), in Saartjie's 'voice' the physiognomy of the opening motive varies from jaggedness to a more lyrical expression, depending on her mood, mellowing towards the end of the opera. Only a few examples are mentioned here. After its introduction, the jagged motive (which consists of a semitone plus a minor sixth) appears transposed in every bar until bar 19, with the exception of bars 9 and 14 (Example 2.1). When she addresses the crowd of revellers, discarding her cloak ('To you I am no more than this', that is, the Hottentot Venus), the large segment shrinks to a perfect fifth in bar 223 (E, F, C against 'I am no'). The original motive reappears when she refers to her reputation, but now rhythmically augmented in bars 239-242 (Example 2.2). When she asks of Elsie: 'Will I cradle you again...?', the motive becomes lyrical, accompanied by gently rocking quartal constructions, before she sings the lullaby (Example 2.3).

Example 3: Saartjie, bars 5-14 (Orchestral introduction) ${ }^{7}$

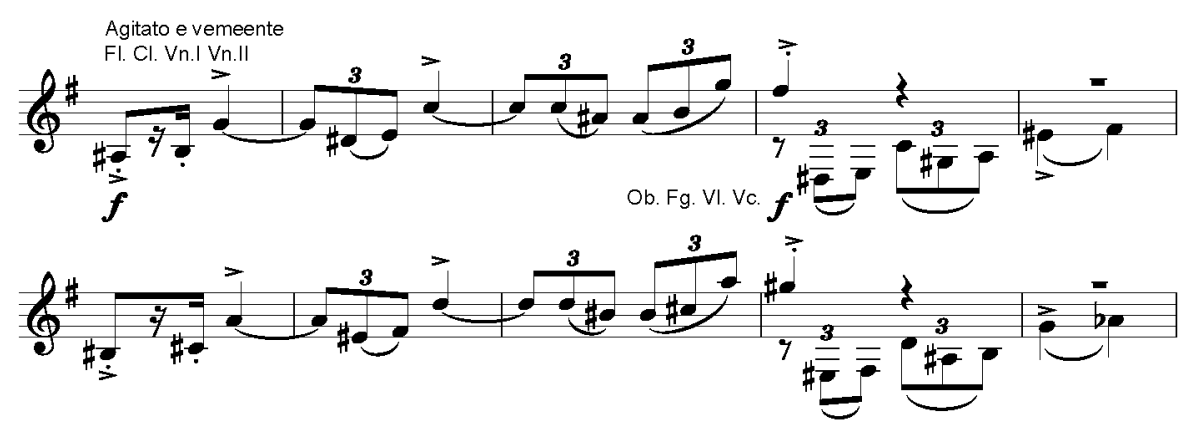

In this example the parts for flute and oboe have been written an octave lower and the parts for bassoon and violoncello an octave higher. The score is presented here in a condensed format. 
Example 4: Saartjie, bars 240-243 ${ }^{1}$

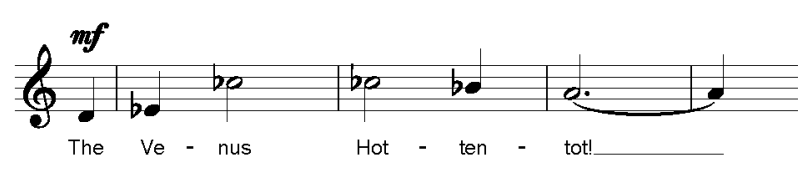

Example 5: Saartjie, bars $480^{3}-482^{3}$

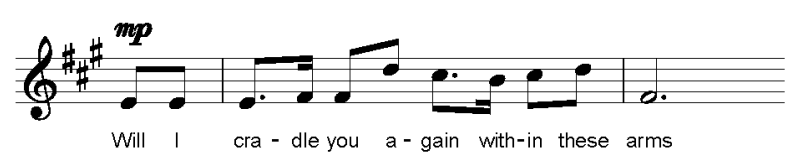

The end of Saartjie's inner journey is reflected in a more coherent lyrical expression, devoid of the jagged motive, its large segment only appearing as an expressive final gesture, and the approaching semitone, now from above, is contained within the leap, when she sings with 'The Voices of the Ancients' that 'I have come home!'

When the audience returns after interval for the remaining operas, they see prison bars stretching from left to right across the stage and are thus forcefully plunged back into a dark past. Based on the prison poetry of Breyten Breytenbach, Martin Watt's Tronkvoël (Jailbird) opens with static, silent figures behind bars, frozen in various poses signifying despair. The bright light behind the figures reduces them to black 'statues', as impersonal as the nameless secondary characters Swartman, Boerseun, Hond ('Black Man', 'Young Afrikaner', 'Dog') and as dehumanised as the reference in the title of the opera. The image reminds one of the 'hundred thousand bars, and behind the bars, nothing' of Rilke's The Panther (Bly 2006), and also of the high fence surrounding Saartjie Baartman's grave on a lonely hill near Hankey in the Eastern Cape, symbolising her entrapment at the end of her life, cut off from her family and friends.

Martin Watt uses only the string section of the prescribed orchestration because, according to the librettist Alwyn Roux, Breytenbach heard these instruments in his head while in jail (Watt 2010a). The players are instructed to play without vibrato to suggest bareness and austerity. It was not the composer's intention to link any musical symbols to Breytenbach's poetry, but rather to create a specific atmosphere. The libretto is in Afrikaans because, amongst other reasons, Breytenbach is well known for his outspoken concern about the future of the language (Watt 2010b).

Being convicted of high treason, Breytenbach spent two years of his seven-year sentence in solitary confinement. He writes how he stared at the brick wall for hours, his mind a blank. The nine scenes of the opera are a musical depiction of Breytenbach's barren inner world. During the performance one notices the poet's empty eyes staring 
into space. When Yolanda, his wife, tells him in the penultimate scene 'Ek wag vir jou in 'n goue begraafplaas in Rome' ('I wait for you in a golden cemetery in Rome'), he replies 'Hierdie ek is dood' ('This I is dead').

Open fifths, suggesting emptiness, are a prominent feature throughout the opera. At the beginning of the opera the parallel fifths played by the cellos and double basses create a gentle rocking movement. The pentatonic effect of the layered entries of the upper strings eventually appears in the descending melodic contours of the Swartman's part ('Yithi cwaka ntlizio yam', 'Be quiet my heart'), his aria being repeated in Scene 7. In the agitated second scene the parallel perfect fifths become jerky and jagged. Boerseun, the warden, shouts 'Pluk sy benerige vlerke af' ('Pluck his bony wings'), referring to Breytenbach's metaphor - a chicken has wings but cannot fly (Watt 2010a). The next scene describes how he stares at the wall for hours, gradually becoming more deranged. In Scenes 4, 5 and 7 the brutality, arrogance and aggression of Boerseun are taken further when he forms an alliance with Hond. The pentatonic effects make way for three-note formations where a semitone is combined with a minor third, with a major third and with a minor sixth, for example an isolated E, F, D ${ }^{b}$ introduced pizzicato by the violas in the second bar of Scene 5 .

The tomato plant, which became a symbol of hope, of a life beyond physical confinement, first figures in the lyrical Scene 6, when Breyten asks: 'Hoe sal jy weet hierdie is die hel?' ('How will you know this is hell?'), concluding with 'Neem my woorde saam met jou, raak groot, dra vrug, ek sorg vir jou soos 'n kind' ('Take my words with you, grow up, bear fruit, I'll look after you as a child').

Example 6: Tronkvoël, Scene 6 (bars $12^{3}-20^{2}$ )

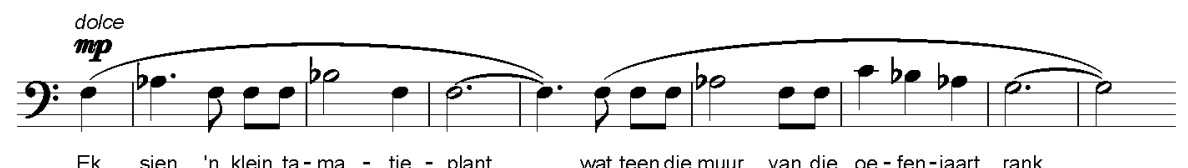

In the first interview after his release in 1982, Breytenbach said:

There are scenes I shall never forget. In the little yard where I took the air, only 15 by 20 feet, a tomato-plant was growing. I cherished that plant as if it were a child. Once after a white man had been hanged there in the morning early (I could sometimes communicate with my fellow-prisoners by shouting) the guard who had just attended the execution plucked a deep red tomato for himself and for me. Together we ate the cold dewy-fresh fruit. The warm corpse was still lying within reach. It was as if I were eating that heavenly fruit on behalf of the dead man. (Roux 2010)

After the appearance of Yolanda as a phantom on an elevated platform (Scene 8), the prisoners join the soloists when repeating 'Senzeni na?' ('What have we done [to 
deserve this]?') through the whole final scene.

Example 7: Tronkvoël, Scene 9 (bars 1-8 ${ }^{3}$ )

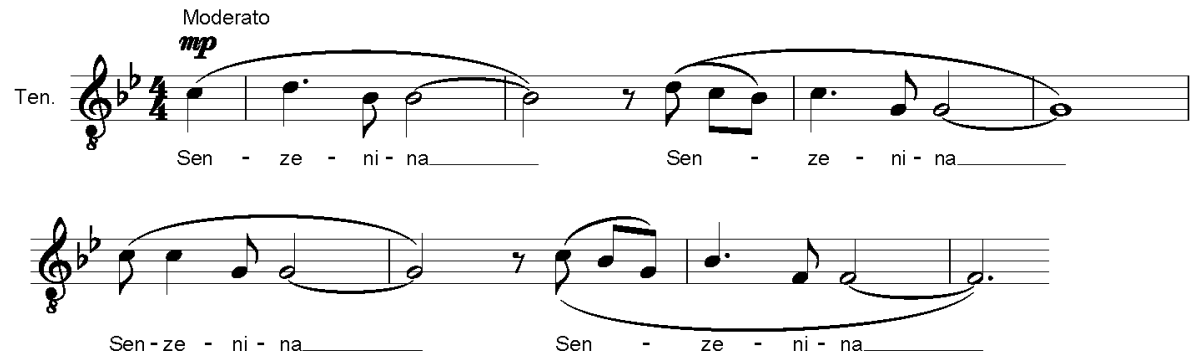

Although the Zulu/Xhosa 'Senzeni na?' ('What have we done?') is known as a struggle song in many variations, and is also sung at funerals and in church, I associate the melody with the Nguni lullaby as it appears in Saartjie. On the whole, the music in the opera, reduced to bare essentials, reflects the uncompromising starkness of the physical as well as psychic environment.

In contrast to the first three South African operas, which deal with well-known South African figures, Peter Klatzow chose Lucy Lloyd as the main character in his opera, Words From a Broken String. She was a linguist who, continuing the research of her brother-in-law, William Bleek, studied the language and culture of the San people in the 1870s. ${ }^{8}$ The opera is based on Pippa Skotnes's book Claim to the Country (cf. Skotnes 2007), which was published with the digital Bleek and Lloyd archive. According to Peter Klatzow, to have been able to work with librettist Michael Williams strengthened his hand, because Williams 'understands language and operatic structures' (2010).

In the opera Lucy meets the San people in her living room. Four prisoners, who work in peoples' gardens while serving their jail sentence, arrive under the supervision of the Constable. Although for Lucy Lloyd the purpose of this visit was to record their language, for the Constable the prisoners are criminals known only by their numbers. When introducing them to Lucy in military style, he recites their numbers individually, adding their crime, as well as the name by which each one is known in the wider community. However, when they introduce themselves, they give their San names: /A!kunta, //Kabbo, Dia!kwain and Ihan $\neq$ Kass'o respectively. Each one mentions

\footnotetext{
The composer consulted the Bleek and Lloyd archive, housed at UCT's Manuscripts and Archives library, Iziko and the National Library. The director of the Centre for Curating the Archive, Pippa Skotnes, was also the interim director of the Gordon Institute for Performing and Creative Arts at UCT.
} 
personal matters in dry, clipped phrases, whether they are hungry, describing the members of the family, having been shot at, and that ' $[\mathrm{w}] \mathrm{e}$ worked with the earth; we carried the earth. We worked at the road.'

Example 8: Words From a Broken String (//Kabbo, bars $\left.26^{3}-37^{2}\right)$

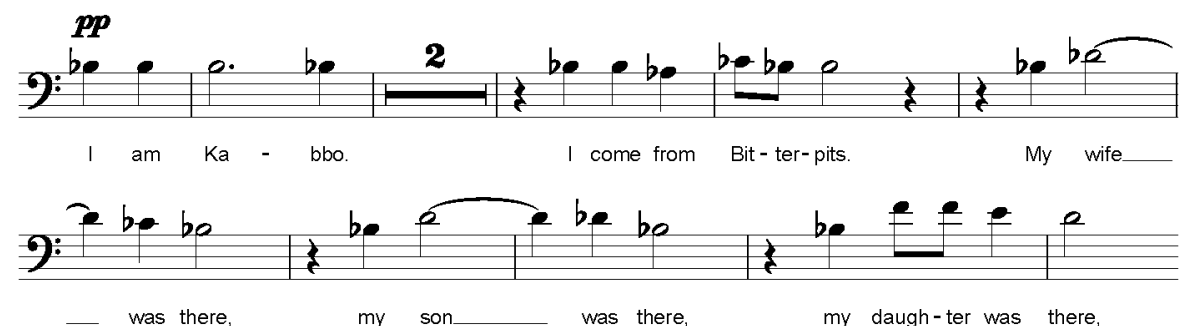

Whereas the Constable regards them as 'savages and mongrels' ('Why anyone would want to talk to the likes of them is beyond me!', bars 129-135), Lucy is trying to interact on a personal level, telling //Kabbo, for example, that ' $[\mathrm{b}] \mathrm{y}$ way of words your stories will live forever'. Continuing in her elegant melodic style, the three verses of the aria which each begins with 'The day begins as it always does', address her former fiancé, then her brother-in-law and, finally, in the third verse, //Kabbo. The strophic structure reflects in a gracious manner an orderly mind (Klatzow 2010).

Example 9: Words From a Broken String (Lucy, bars 254-261)

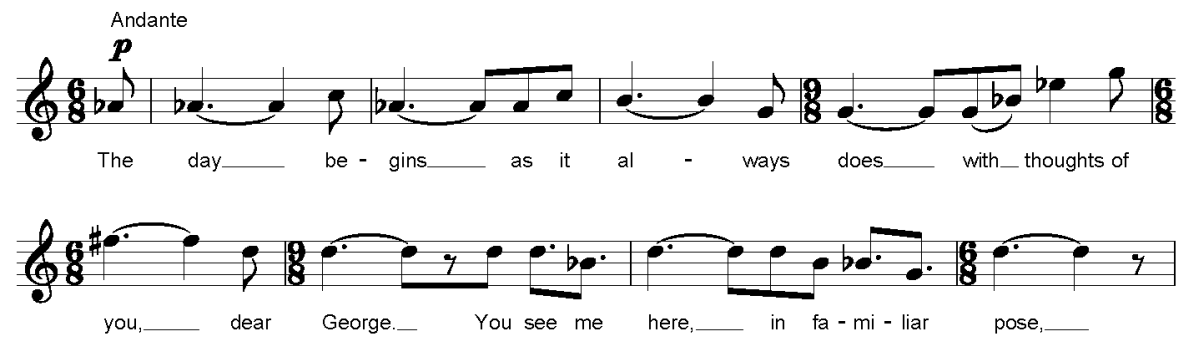

//Kabbo repeats the words of the final phrase ('All people become spirit people when they die') and continues: 'They no longer have their thinking strings, they have no understanding'. This comment could point to the title of the opera, suggesting here that 'broken string' refers to a lack of understanding. Lucy listens to the philosophies of the four San people, trying to capture their soul (bars 317-319), not only their words. The plaintive tenor of Dia!kwain's words reflects the destiny of the San people: 'I am the song of the broken string. Sung by the dying magician. I am the place where all who die 
must go, where words are no longer spoken' (bars 459-487).

Example 10: Words From a Broken String (Dia!kwain, bars 459²-471)

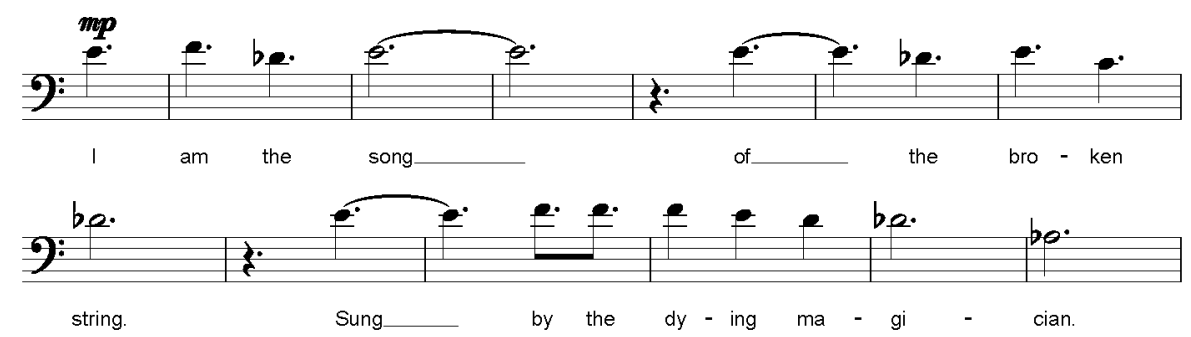

Although this musical tribute to the San people is rich in meaning, only three levels of signification can be mentioned here. Firstly, on a physical level the apparent desolation of the San landscape, and even its straight horizon is musically represented by the almost static, seemingly one-dimensional vocal lines of the four San characters. Secondly, the simple rhythmic structure and the absence of melismas, contrasting with the more florid melodic physiognomy of Lucy's music, suggest a kind of timelessness in which rhythm and pitch serve the text, highlighting not only the nature of Lucy's project (the study of words), but also the importance of words in the opera. 'Words' is not only the first word in the title of the opera, but the front page of the score acknowledges the equal important role of the verbal text by calling the work an 'opera in one short act by Peter Klatzow and Michael Williams'. Indeed, the importance of words reveals a third level of signification, where the spiritual ideas expressed in words transcend the immediate physical worlds of Lucy and the San people, symbolising on a metaphysical level an inner landscape which is communicated through metaphors that are inextricably linked to the San heritage.

The opera that ends an evening of mostly dark themes, provides some lighter moments. Péter Louis van Dijk specifically decided to use a South African mini-bus taxi as the central concept for his opera, Out of Time, because immediate relevance was important for him, even though he does not like taxis. The composer also wrote the libretto for the eight short scenes, the opera ending 'as abruptly as it begins: "Faceless. Anonymous" and out of time' (Van Dijk 2010). The moving off and stopping of the fast-moving taxi is convincingly mimed by the passengers on board. By having the soloists double for other characters and by having the chorus represent different groups of people (Bystanders, Commuters, Animals, Greens, Opportunists), the opera appears much broader in scope than the actual number of performers suggests. 
Birds and taxis are funny, says Vox (the narrator), watching the taxi with Gaartjie (fee collector), Abacus (driver), Beauty and Tata (Vox's future parents) and other commuters arrive in a chaotic way in the first scene. In the second scene (Twelfth Street), the thumping taxi music with its prominent repeated A minor triad was prerecorded with the assistance of Gerard Roux. Opening with the descending contours of a horizontalised A minor and F minor triad, Gaartjie asks 'Do you know where you are going to? [...] And do you go where you want to go?'

Example 11: Out of Time, Scene 2 (Twelfth Street), bars 50-57

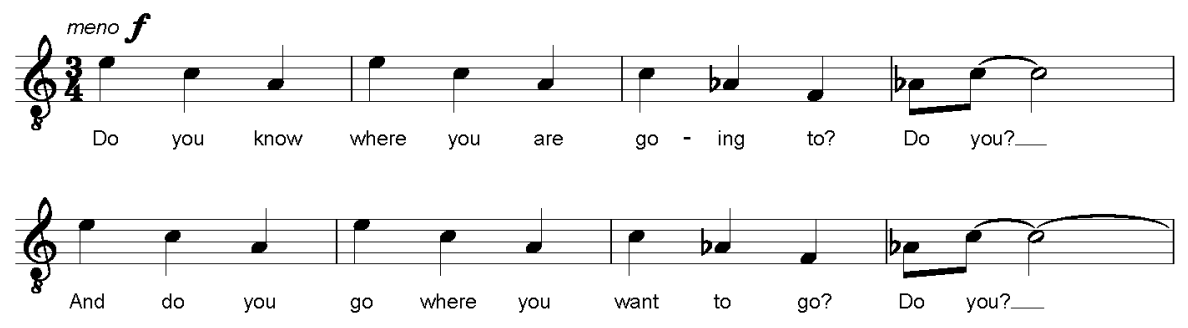

After the chorus joins Gaartjie, he refers to 'People waiting for a sign, People standing in a line, People in and people out of time' (bar 126). His 'Hurry, hurry!' is accompanied by nervous, agitated music. When getting out of the taxi, Beauty and Tata accidentally bump into each other and freeze as their eyes meet. In the absence of words, the sensual play with their umbrellas in the misty rain represents the language of love, and large, expressive leaps in the vocal and instrumental parts create an expressive musical language (Scene 3).

Each of the following scenes also presents a new theme. In the scene described as 'Greenophobia', the xenophobia is aimed at the Greenies. When bystanders intimidate Tata and Beauty, the prominence of major thirds and diminished fifths in the vocal lines creates an initial whole-tone field, which corresponds with the whole-tone chord at the beginning of the opera. Vox describes his birth in the taxi in the scene entitled 'Nativity Street (The Miracle)', while Gaartjie calls out in desperation 'Great! A mid-wife crisis!' Vox's birth is celebrated by two birds singing coloratura arias in Baroque style while, according to the instructions in the score, his father shows 'signs of anxiety as the birds become more frenetic'. In Scene 6 ('Fast Talk and Laughing Stop (Fable)') Tata proclaims: 'And God took pity on the people, saying: "I shall take the precious gift of language from the animals and give it to you. And I shall give you dominion over the earth and give you a soul - and a conscience". The character 
Politpurple latches onto the idea of 'dominion' and Politgray wonders 'Can one sell a soul - or a conscience?' The chorus of opportunists shouts 'Mine! Mine! Mine!', while desperately wrestling over imaginary objects. After trying to convince the electorate to vote for them, stressing the fact that numbers count, the Polits suddenly realise that they have a common purpose, namely to cleanse the country of the Greens. The contour of previous triadic thematic structures now changes from descending to ascending when the Polits count votes or money, 1-3-5-9 and 2-4-6-10 melodically represented, for example, by C-E-G-D and D-F-A-E respectively.

In the penultimate scene Tata shaves himself with an old-fashioned razor, while Beauty sings an Arietta, lamenting 'How could I know it would end this way? Words were the razor that cut you so deep'.

Example 12: Out of Time, Scene 7 (Peek-a-Boo), bars 558-565

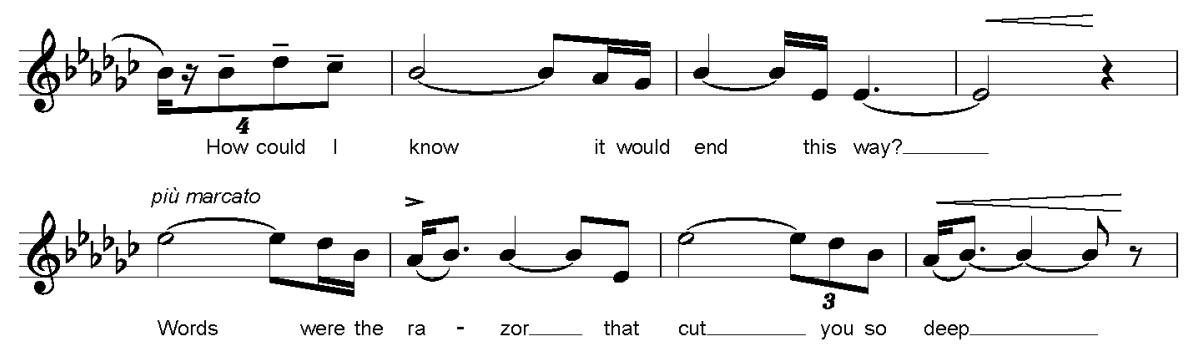

The birds' whole-tone music returns creating, according to the score, 'an everincreasing cacophony of off-stage bird-calls'. Tata deliberately cuts his throat and the stage is lit by the glow of burning cars and shacks. In the final scene ('Terminus') the baby on Beauty's back is shot when an angry mob attacks the Greens. The descending contour of a horizontalised A minor triad features prominently when the Greens shout 'Hell is upon us' and two falling fifths, E-A and C-F, the outlines of the triadic melodic formations of Gaartjie's song in Scene 2, accompany 'raping, shooting'.

Coherence is created not only by means of pitch structures but also by extramusical references. For example, the music of the birds creates a line of development in the opera, culminating in Tata's psychological breakdown. If the taxi ride is regarded as more than just a theatrical journey, it could also signify abstract ideas. Firstly, travellers as a group can represent the electorate following populist political leaders in a 'sheeplike' fashion. Secondly, the hectic rushing around, accompanied by the repeated 'Do you know where you are going to?' could be regarded as a comment on modern life, and thirdly, the permanent moving from point to point could also symbolise the 
shifts between the commentary of the narrator (Vox) and what actually happens on stage, blurring the boundaries between past and present.

By staging five contemporary operas on contentious, relevant topics and doing so in an accessible musical language, the Five:20 project has filled a niche in the cultural life of this country. And it has done so with authority and conviction, demonstrating a high level of musical craftmanship. However, a number of questions may well be asked: Why all these dark themes? Are there no lighter moments in the lives of South Africans? But, on the other hand, we could also ask: should artists only entertain the public or should they also reflect broader social issues? By holding up a mirror, they show us: This is you/us. The metaphor of the mirror appears in the answer to the Greens' question in Out of Time: 'Why do you persecute us?', to which the mob responds: 'You are our mirror, our fearful mirror. You must die lest we see ourselves in you'. These operas also show us various kinds of fences, bars and barriers, physical and psychological. Listening and understanding their messages could help to break down these obstructions to stimulate new ways of thinking and new ways of doing.

\section{References}

Bly, R (2006). Translation of The Panther by Rainer Rilke. $<$ http://www.thebeckoning.com/poetry/rilke/rilke1.html $>$ accessed 11 December 2010.

Brommert, B (2010). 'Next 48 Hours Review: Five20.'

$<$ http://www.capetownopera.co.za/2010/11/29/next-48-hours-review-five20/> accessed 31 December 2010.

Chisholm, F (2010). 'Opera unveils real deal about Saartjie.' Cape Argus, 5 September. $<$ www.capetownopera.co.za> accessed 14 December 2010.

Crais, C C \& Scully, P (2009). Sara Baartman and the Hottentot Venus: $A$ Ghost Story and a Biography. Princeton: Princeton University Press.

Henry, Z (2010). “"Bonsai opera” revitalises genre.' Cape Argus Tonight, 31 August. $<$ www.capetownopera.co.za> accessed 18 December 2010.

Hofmeyr, H (2010). Personal communication, Cape Town, 24 November.

Irish, D (2010). 'Flashes of beauty sparkle in feast of short works.' Cape Argus, 25 November, 16.

Klatzow, P (2010). Personal communication, Cape Town, 24 November.

Muller, W (2010). 'Opera op sy kop gekeer.' Die Burger, 19 November. $<$ http://sadailynews24.com/search/?q=opera+op+sy+kop+gekeer $>$ accessed 30 December 2010.

Ndodana-Breen, B (2010). Personal e-mail correspondence, 25 November.

Programme Notes (2010). Five:20 Operas Made in South Africa. 21-27 November. Cape Town: GIPCA. 
Rutter, K (2010). 'The struggle continues.' Sunday Times, 21 November. $<$ http://www.timeslive.co.za/sundaytimes/article768640.ece/The-struggle-continues> accessed 25 November 2010.

Roux, A (2010). 'Interview with Phil van Schalkwyk', July 20, $<$ http://www.pyponline.co.za/?tag=tronkvoel $>$ accessed 31 December 2010.

Skotnes, P (2007). Claim to the Country: The Archive of Lucy Lloyd and Wilhelm Bleek. Johannesburg: Jacana Media and Athens: Ohio University Press.

Van Dijk, P L (2010). Personal communication, Cape Town, 24 November.

Vavi, Z (2010). 'What would Chris Hani say today?' Chris Hani Memorial Lecture, Congress of South African Trade Unions (COSATU), delivered in Queenstown, 23 October.

$<$ http://www.cosatu.org.za/show.php?include=docs/pr/2010/pr1023a.html\&ID=41 40\&cat $=$ COSATU\%20Today $>$ accessed 12 December 2010.

Watt, M (2010a). Personal communication, Cape Town, 24 November.

Watt, M (2010b). 'Martin Watt on "Tronkvoël”".

$<$ www.youtube.com/watch?v=I8dvV6YqChk> accessed 20 November 2010.

\section{Scores}

Hofmeyr, H (2009). Saartjie.<Hendrik.Hofmeyr@uct.ac.za>

Klatzow, P (2009). Words From a Broken String. <peteklat@mweb.co.za>

Ndodana-Breen, B (2010). Hani. <bonganinb@me.com>

Van Dijk, PL (2010). Out of Time. <plvdijk@iafrica.com>

Watt, M (2010). Tronkvoël.<Martin.Watt@uct.ac.za> 